\title{
Digital Lifelong Learning and Higher Education: multicultural strengths and challenges in pandemic times
}

Ana Ivenicki a*

\section{Abstract}

The paper aims to discuss digital learning for lifelong learning at the university level in Brazil, taken as a case study. It is structured in the following way. It presents concepts of digital learning in multicultural approaches within lifelong paradigms. It then presents a cursory look at Brazilian educational policies in that area, particularly focusing on the role of the Universidade Aberta (Open University) in Brazil. Lastly, it discusses digital learning in the context of the onset of the COVID-19 pandemics in Brazil. It tries to gauge the impediments and the challenges that may jeopardise a multicultural potential in educational policies, particularly focusing on government political directives as well as responses from university associations and from a public university. It concludes, by presenting possible ways ahead for reflections and contributions in the area.

Keywords: Digital Learning. Lifelong Learning. Higher Education. COVID-19. Multicultural Perspectives. Educational Policies. Brazil.

\section{Introduction}

In a technological era and in the middle of the COVID-19 pandemics, more than ever digital learning has been at the centre of the discussions in the educational field. In Higher Education, on-line remote digital strategies have been the means by which courses and other university activities have been under way, given the fact that social isolation has been the rule for almost all the countries in order to avoid the widespread of the corona virus in the COVID-19 pandemics.

However, digital learning has already been part of the discussions concerning lifelong learning before that. In fact, there seems to be a strong idea that lifelong

\footnotetext{
a Universidade Federal do Rio de Janeiro, Rio de Janeiro, RJ, Brasil.

* Bolsista 1A do Conselho Nacional de Desenvolvimento Científico e Tecnológico, Rio de Janeiro, RJ, Brasil.
} 
learning strategies need to answer to the growing need for advanced digital competence for all jobs and for all learners (ALA-MUTKA; PUNIE; REDECK, 2008). However, it also seems to be central that digital learning is not about technology on its own, but mostly about learning itself.

As claimed by Slowey and Schuetze (2012), the complexity of the concept of lifelong learning masks a fundamental conflict between, on the one hand, a model of lifelong learning derived from principles of social justice and equity and, on the other, a model geared towards market oriented concerns and informed by human capital perspective. In a social justice and multicultural perspective, we argue that effective lifelong learning is likely to happen when digital curricular contents have been embedded with inclusionary strategies that foster plural students' critical thinking and empowerment.

In that sense, some key questions are: What possible ways could be thought of so that digital learning provides both meaningful learning and the strengthening of cultural identities of lifelong learners? What strengths and what weaknesses does digital lifelong learning present, within a local cultural context- Brazil, particularly in the pandemic context of 2020 ?

In order to answer to those questions, the paper aims to discuss digital learning for lifelong learning at the university level in Brazil, taken as a case study. It is structured in the following way. Firstly, it presents concepts of digital learning in multicultural approaches within lifelong paradigms. It then delves in the context of Brazilian educational policies in that area, particularly focusing on the role of the Universidade Aberta (Open University) (BRAZIL, 2006) in Brazil. Lastly, it discusses digital learning in the context of the onset of the COVID-19 pandemics in Brazil in 2020. It tries to gauge the impediments and the challenges that may jeopardise its multicultural potential, particularly focusing on government political directives as well as responses from university associations and from a public university, in the context of the urge to promote digital learning in the pandemic of COVID-19, in 2020. It concludes, by presenting possible ways ahead for reflections and contributions in the area.

\section{Digital Learning and Lifelong Learning: the case of Brazil}

Digital learning can be understood as learning that is developed with the aid of technology. Concerning lifelong learning, authors such as Milana (2015) hold that the process of lifelong learning builds on the idea that personal, social and professional development and continual learning happen throughout life. 
Additionally, as claimed by Slowey and Schuetze (2012), lifelong learning has been conceived within two competing agendas. On the one hand, one in which Higher Education should have particular relevance for lifelong learning inasmuch as it prepares lifelong learners for the increased marketization and as a drive for the development of a knowledge economy that arguably requires a well-trained, flexible and adaptable workforce. On the other hand, an equity-oriented agenda, in which lifelong learners are perceived as subjects with cultural views and economic and social backgrounds that need to be taken into account in order to ensure a more equitable and social just society.

The need to link lifelong learning with digital learning has been increasingly felt with the development of technologies that should arguably allow adult students to have access to a wide range of information in virtual platforms and dimensions. In fact, according to Ala-Mutka, Punie and REdeck (2008), lifelong learning strategies need to answer to the growing need for advanced digital competence for all jobs and for all learners. In that sense, digital learning should be relevant for individual, professional, leisure and personal growth, apart from yielding more flexible forms of Higher Education provision for lifelong learners.

In order to discuss digital lifelong learning and the role of Higher Education in Brazil, a cursory look at its contextual scenario is relevant. Brazil can be considered a multicultural country, with considerable challenges in terms of educational and social inequality. Its population is of 208,5 million people, and it is the biggest country in South America. However, access to higher education is of $32.7 \%$ of people between eighteen and twenty- four years old (NITAHARA, 2019), configuring social inequality of the intake to Higher Education. Such a situation seems to look like what Álvarez-Mendiola (2012) points in relation to Mexico, where there still is a required universalization of Higher Education in order to foster an educational system governed by lifelong principles. Some attempts to address this problem have included entry quotas to Higher Education in public universities for black and indigenous groups; government student financing programmes aimed to place academically qualified low-income students into private Higher Education institutions; fostering the increase in night Higher Education courses and courses of shorter duration, among others.

Statistics should be relevant at this point, in order to have a glimpse of the role of the public and the private sector in Higher Education in Brazil. Data before the onslaught of the pandemics showed that the participation of the private sector 
of Higher Education was 75\% in 2017 (INEP, 2018), which means that for each four Higher Education students, three were attending private institutions. Also, data from the same source (INE, 2018 indicated that distant learning increased in $17,5 \%$ in that year, representing $21,2 \%$ of undergraduate Brazilian students. Focusing particularly on teacher Education courses, 46,8\% attended distant courses and $53,2 \%$ on-site ones. It should be noted that such percentages drop when analysing the public sector, where $81,7 \%$ of students attend on-site courses against $18,3 \%$ in long distance ones, compared to $64,1 \%$ that attend long distance courses in private Higher Education institutions against 35,9\% in on-site ones (INEP, 2018). However, the percentage of those that got into the system and those that fell out of it also calls the attention, drop-out being high. In fact, for each 1000 inhabitants, 31,5\% entered Higher Education institutions and 12,3\% dropped out.

Against that background, distant Higher Education courses have also been in place, and they have been the focus of educational policies both at federal, and at state and municipal levels. Before internet and digital learning, printed media, visual objects and other technologies have been used in extension/community educational projects by Higher Education institutions, as well as for distant higher teacher Education courses.

In 20, a landmark in digital lifelong learning in Brazil was created, namely the Universidade Aberta do Brasil (Open University of Brazil) (BRAZIL, 2006). It is a distance Higher Education program developed by a consortium of Brazilian public universities geared at offering on-line Higher Education courses, so far being focused on teacher initial and continuing Education. As gleaned from the document referring to it (BRAZIL, 2006), such a program aims to amplify and disseminate to far-off regions in Brazil courses and programs of Higher Education, prioritising teacher initial and continuing Education, including the provision of Higher Education for those teachers who do not hold Higher Education certificates, and who already act in Brazilian schools. As gleaned from the referred policy document, the Brazilian Open University (BRAZIL, 2006) allows students to get in touch with tutors and professors, as well as have access to libraries and laboratories of information technology, biology, chemistry and physics.

The policy document also talks about developing a national distance online system of Higher Education in Brazil that values cultural diversity, including adult Education, Education for human rights, for ethnic and racial relations, gender identities and other themes, therefore within an equity 
and multicultural agenda, at the level of intentions. As posited by Ivenicki (2018; 2019), multicultural sensitivities in Brazilian educational policies tend to be present side by side with the need to situate Brazilian Education positively in the global, technological world. Such a trend seems to be present in the referred document of the Brazilian Open University, which also tries to articulate local, inclusionary and anti-racist concerns with more global curricular scopes in lifelong learning.

In terms of digital learning, the Brazilian Open University has been employing hybrid systems, partly normally requiring students to be present for end of year exams, and most of the part being developed on-line (it counts on 555 "poles" or main places in Brazilian municipalities, where computers are available for students).

It is noteworthy that even though such a program can be considered a relevant point in digital learning for lifelong learners, the fact that it has been covering only teacher Education courses conveys its limitations in that area. On the one hand, that seems to confirm a trend in Brazilian educational policies concerning lifelong learning once again similar to what Alvarez-Mandiola (2012) has pointed in relation to Mexico, namely that lifelong learning initiatives tend to lack a cohesive national system to support it. In fact, a lifelong learning framework is still missing in Brazilian and Latin American policies in general. Such a framework could arguably provide a more coherent, explicit lifelong national policy to address the needs for continuing Education of highly heterogeneous learner populations. However, it should be pointed out that economic resources should be increased in order for that to happen, other priorities still being in need to be faced in the Brazilian reality, such as literacy development, teachers' salaries and infrastructure of schools, among others.

On the other hand, polarisations have been present ever since, between those that have considered the possibility of high quality digital distant learning in Higher Education against those that have systematically shunned that idea in favour of the so-called "superiority" of on-site Higher Education courses. Such dichotomic and polarised perspectives have led to what some in Brazil call as a "missed opportunity" to extend the scope of the Universidade Aberta do Brasil, (BRAZIL, 2006) as well as other means to boost digital learning Higher Education courses and experiences, in all areas, including lifelong learning.

Even though it is not the aim of the present paper to make a deeper analysis of policies, it is useful to note that other educational policy documents - namely 
the National Plan for Education (BRAZIL, 2014) (that refers to educational plans for the decade between 2014 and 2024) and the Future-se ("Get into the Future") Plan (BRAZIL, 2019a) (that refers to a project for Brazilian public universities, still under hot discussions and consultation from the academic community) tend to also confirm the trend to understand lifelong learning as related to teacher Education and teacher continuing Education. Relatedly, they tend to employ the expression "adult Education" as geared towards promoting literacy and numeracy skills for the illiterate marginalized groups, rather than include adult Education in a possible lifelong learning framework that would provide a system to cater for those adult students throughout life. Also, those documents tend to view digital learning as a value in itself as opposed to linking it to transformative, multicultural concepts of learning, taking into account Brazilian cultural diversity (CANDAU; MOREIRA, 2008; IVENICKI, 2018, 2019). That seems to be clear, for example, in the Future-se plan (BRAZIL, 2019a), when it talks about internationalisation of Higher Education as one of the goals, stating the importance of "facilitating the access and promotion of the teaching of disciplines through platforms on line".

In fact, digital learning as part of distance Higher Education lifelong learning has been object of different feelings up to now. On the one hand, it has been recognised as an important means to provide Education and teacher Education within contexts of large countries as Brazil. In those cases, it has been pointed as the main avenue for what has been called as the "interiorization" of university in the most remote Brazilian areas, meaning that students in cities and little towns away from the big centres have the opportunity to attend classes and become teachers attending virtual classes. In that sense, as the Future-se (BRAZIL, 2019a) document points out, it has also been understood as a means to make Brazilian public universities more international, through the exchange of ideas in platforms on line. Evidently, other factors should be considered when talking about internationalisation, particularly linked to language issues in a context where Portuguese is the main communication means for most of the population, in detriment of English as an hegemonic one.

On the other hand, however, those on-line distance courses that build on digital learning have also been charged with deepening social inequalities insofar as a minority of students in peripheric countries have access to digital learning. Additionally, from the pedagogical perspective, digital learning has also been viewed by some as providing lesser possibilities for transformative Education, being tantamount to exchange of ideas and to the exposure of differences that presence learning allows. 
Going beyond those dichotomic ideas, the onset of the COVID-19 pandemics in Brazil brought to light digital learning and its challenges, as well as its potentials and contradictions, to which educational policies, as well as Higher Education institutions and actors, have been called to respond.

\section{Digital Learning and Educational Policies in 2020 Brazil: challenges and potentials uncovered by the Pandemic of COVID-19}

The onset of the pandemics of COVID-19 in 2020 made an astounding mark for digital communication and digital learning worldwide. In fact, as claimed by Dias and Pinto (2020), the COVID-19 crisis resulted in the end of classes in schools and universities, affecting more than $90 \%$ of the students in the world.

In multicultural and unequal countries such as Brazil, there were mixed effects related to multicultural and equity sensitive concerns. Those concerns related to both aspects referred to the challenges of access to digital artefacts, as well as to the articulation of digital learning and curriculum practices.

Brazilian news has consistently pointed out that most students in Brazil, including adult students, have not had access to digital learning in order to be able to attend on-line courses. On $20^{\text {th }}$ May 2020, after strong pressure from academics and students, the Ministry of Education decided to postpone the National Exam for the Secondary System (Enem), that was due to take place in November 2020, due to the inequality of access to on-line classes for most of the population. That was an important decision bearing in mind the aforementioned toll of entry into Higher Education in Brazil, which is very low compared to international standards.

Such an unequal access to on-line and digital artefacts has also been felt at the Higher Education level itself. The panacea by which digital learning has been perceived in educational policies suffered a reality check. The lack of access to digital technologies in order to be able to attend on-line Higher Education classes also impinged on the decision of most of public Brazilian universities to suspend the academic calendar of 2020 rather than go on with it through on-line and digital learning strategies.

On the other hand, the Conselho Nacional de Educação (Brazilian National Council of Education) (BRAZIL, 2020a), which is a counselling federal institution that advises the Ministry of Education about educational affairs, 
issued a directive to be taken in the pandemic times, towards distant digital learning in Brazilian schools (BRAZIL, 2020a), which suggests measures based on digital learning should be adopted during the pandemic period by schools and Higher Education institutions.

Concerning the last ones, the referred document starts by acknowledging that the census carried out by the National Institute for Studies and Educational Researcher Anisio Teixeira (Inep) confirms that Brazil has 8.740.338 students in all areas and courses, and distant on-line courses covers $40 \%$ of the total of 3445,935 of the students that entered both in the private and public sectors of Higher Education in 2018, the public sector of Higher Education being responsible for 60000 registrations of students. The CNE document (BRAZIL, 2020a) also states that registration of students in on-line distant Higher Education courses doubled since 2008, particularly emphasising, once more, teacher Education courses.

On the other hand, it states that even though 7.170.567 places were opened for Higher Education on-line distant courses, both in private and public Higher Education institutions, only $19 \%$ of them were filled. The possibility of all Higher Education courses providing $40 \%$ of their curricula on-line was suggested in another Ministry of Education document (Law n ${ }^{\circ}$ 2.117/2019 [BRAZIL, 2019b). However, the extent to which institutions have (or have not) adhered to that model has not been assessed so far.

It is important to note that even though distant learning has been central to protect lives, the lack of conditions to use technological means has been a deterrent to the success of that mode of learning, both for the public and the private sector. In fact, change of $40 \%$ of on-site courses to long distance ones in the private sector, for example, has resulted in the demise of Higher Education faculty and the ensuing increase of classes with overload for those remaining faculty, as well as the dropping out of students, as mentioned before.

That way, even though distant on-line courses in Brazil apparently increased, the referred document states that it still lacks a more widespread coverage. It then goes on to stress the importance of widening the offer of distant on-line Higher Education courses, and to offer conditions so that the access to technological computer platforms may be successful (even though it is not stated how that could be done). The document specifically refers to the importance of hybrid mechanisms (such as the Open University referred to in the last sections of this paper), and goes on to refer to the COVID-19 pandemic and to the Portaria 
(Norm) MEC (Ministry of Education) n $n^{\circ} 345 / 2020$ (BRAZIL, 2020b) that gives authorization, in an exceptional way, for Higher Education institutions to change on-site classes by others that use digital technologies, including theoretical disciplines of the course of Medicine, with the exception of laboratories and teaching practice disciplines.

Also, it suggests that extension Higher Education projects - which are those geared towards society at large, including lifelong learning projects - should also be benefited by digital technologies in areas such as teacher continuing Education; environmental Education and sustainability; human development and social responsibility; supporting teachers and future teachers in creating digital curricular materials; and educational actions geared towards preventing the contamination by COVID- 19 .

Additionally, the referred document recommends that Higher Education institutions should replace on-site classes by remote, distant learning classes through digital technologies, including assessment practices, as well as organise teacher training in a way that could prepare teacher educators to deal with those. Among those measures, there also is the recommendation that the entry selection of students should also be done in a digital way, and that Higher Education institutions should make use of social media such as WhatsApp, Facebook, Instagram etc., in order to foster and supervise studies and projects.

Reactions from Higher Education institutions were mixed. As public universities in Brazil have autonomy, their senates should decide about the academic year calendar and the extent to which government recommendations are feasible.

A public university in Rio de Janeiro, taken as a case, issued some documents relative to digital learning in which concerns were expressed relative to both students' access to those technologies and to Higher Education professors' training in order to develop digital materials and deliver on-line classes. On 22d March 2020, the office of the high echelon of the University issued a document relative to on-line digital Education in times of the pandemics of COVID-19. The document states that in spite of the passing of the norm by the Ministry of Education that recommends the substitution of on-site classes to on-line digital ones, namely the Portaria ${ }^{\circ} 345 / 2020$ (BRAZIL, 2020b), there should be a concern about equity educational issues, since there are lots of students from lower economic strata, as well as those with special Education needs, who would be unequally treated in such a curriculum due to the fact they would not be able to have access to digital technologies in an 
efficient way. That way, the document states that while the pandemic lasts, virtual digital platforms should be employed only in those classes in which such technologies were already in use, stressing that digital technologies should not replace present, on-site classes at the University. It concludes by suspending the academic university calendar until the pandemic will have been under control.

\section{Future Perspectives and Possibilities for Digital Lifelong Learning}

What perspectives can be drawn from the Brazilian case? Firstly, the onset of the pandemic and its impacts on Higher Education and lifelong learning tend to uncover challenges that had already been present in educational realities. On the other hand, in a constructive and positive way, it can serve as an incentive to improve those areas in which educational inequality and curriculum development deficiencies have been pervasive.

In fact, local national case studies can be relevant comparatively, in that they provide insights into ways by which local cultural contexts either replicate or produce political narratives that can be useful for comparative and international perspectives. Authors such as Kubow and Blosser (2016) contend that Education has increasingly been informed by individual and collective experiences. They posit that multicultural and comparative approaches should have a central role to play in developing both local and global perspectives to aid Education policies and practices.

Against that backdrop, it is noteworthy that there remains significant disparity within countries in terms of access and equity opportunities in Higher Education, including lifelong learning and digital learning, which became even more apparent during the Corona virus pandemic of 2020. In terms of digital lifelong learning, in highly culturally diverse and socially unequal countries, policies for lifelong learning should arguably consider the extent to which digital learning should be fostered so that digital lifelong learning should be wary of enhancing learning for only a few. In that sense, digital lifelong learning should not contribute to perpetuate educational inequality.

In terms of pedagogy, it seems to be clear that concepts of learning and digital learning should be developed hand in hand. The fact that teachers and Higher Education professors have been asked to develop digital materials without having been prepared for that should be seriously considered. Also, as argued 
by Araujo, Oliveira and Barcellos (2020), when schools reopen again, strategies such as increasing schooling time or the use of technologies should be unlikely to have impact on the achievement of students. They suggest some measures such as making a more efficient use of time, with intensive tutorship focused on marginalized students should be more efficient.

We claim two lessons may have been learned from the pandemic time, concerning digital lifelong learning and Higher Education. Firstly, that digital learning is foremost about learning itself. In that sense, it is pivotal to clarify what meaningful learning means in the context of lifelong learning, and to what extent teachers are equipped both with the digital technologies and with the curricular and pedagogical strategies aimed at fostering that kind of learning.

The second aspect refers to equity and social justice educational policies that should be considered within the local contexts where digital lifelong learning is developed. That aspect should be considered in a multicultural, equity-oriented paradigm in lifelong learning. Within that framework, it is central to problematise the extent to which educational policies target heterogeneous access to technology, particularly in highly unequal societies.

Concerning the first aspect referring to learning, in a multicultural perspective, authors such as Candau and Moreira (2008) and Ivenicki $(2018,2019)$ call the attention to the need to understand adult learners' plural cultural contexts and identities so that effective learning could happen. Moreira et al. (2017) illustrate that need, by expressing how adult learners' cultures and ways of life seriously impacted the result of the digital on-line distant course they organised for Higher Education professors. They showed that one of the most relevant weaknesses was the lack of time to do the e-activities, especially when a balance was to be achieved between work, family responsibilities and other daily business and the course requirements, aspects that have been present during the COVID-19 pandemics time in several homes where families have been secluded worldwide. Besides the time aspect, another weakness found was that some of the digital tools were perceived as difficult to use, even though the adult students were a group formed by Higher Education professors, which led the authors to consider cultural contexts and meanings in order for digital learning to be successful in lifelong learning - an aspect that has also been strongly felt during the COVID-19 pandemic worldwide.

Multicultural teacher Education should arguably enhance teachers' role in valuing cultural diversity and inclusionary perspectives in the teaching and learning 
process (CANDAU; MOREIRA, 2008; IVENICKI, 2018, 2019). As posited by Lopes, Oliveira and Oliveira (2018), curriculum should include places for the discussions of identity issues such as gender and sexuality, which cannot be silenced anymore. In the same vein, Macedo (2006) suggests that curriculum should not be thought as a universal concept, but rather as a set of provisionary discourses which should embrace plural identities' narratives.

In lifelong learning, Paulo Freire's approach to adult Education and adult literacy has inspired multicultural thinking, in that it highlights the centrality of providing teaching based on generative themes linked to adults' lives for successful curriculum development and literacy competence. Such an approach to learning should be likely to empower students' identities of gender, class, race, ethnicity and others. It should problematise hegemonic narratives and discourses that essentialise knowledges to the detriment of respecting and building upon plural adult learners' cultural contexts and backgrounds. Such ideas should arguably transform higher education curriculum so that it should be more flexible and culturally relevant, being adapted both to on-site learning and digital on-line learning, in transformative approaches to lifelong learners.

In terms of the second aspect related to equity oriented higher educational policies that support lifelong learning, Slowey and Schuetze (2012) stress the relevance of considering adult learners' prior educational paths and their primary motivation for Higher Education study. They cite, for instance, equity adult groups, which are under-represented in Higher Education and the focus of equity policies relating to gender, racial and other identity markers. In the same vein, Nesbit (2015) holds that social concerns, social movements and community developments generate significant interest in lifelong learning and adult Education that challenge dominant forms of knowledge and hegemonic pedagogical approaches. In that perspective, Milana (2015) posits that it is crucial to examine how Higher Education and lifelong learning educational policies can support a more inclusive, socially committed and learner-centred model of learning.

Therefore, digital lifelong learning should not be limited to technology issues. Apart from providing the means for socially and culturally diverse groups to have access to digital learning, other measures should be seriously considered. That way, in order for effective learning to take place, there seems to be a need for supporting teachers and university professors to effectively embed the use of digital technologies in their teaching practices, as well as providing them with support for cultural change in lifelong learning strategies. In a multicultural 
perspective, this means to value cultural diversity and promote ways of using digital learning to support it.

Against that background, the linkage between cultural change and digital learning seems to be central for lifelong learning to happen through digital learning. In that sense, digital learning should be the object of learning, but also the means through which the strengthening of individual and collective cultural identities should happen. Lifelong digital effective learning is arguably boosted when teaching takes into account local cultural differences and provides the strengthening of adults' identities In that sense, teachers' role is highlighted as they continue to be central in planning and developing curriculum strategies that should allow students' critical thinking, multicultural sensitivities and meaningful learning to take place.

In a constructive way to look into the future, the onslaught of the COVID-19 pandemics should give us the opportunity to think about transformative alternatives so that Higher Education could rethink curriculum and pedagogies, in Brazil and worldwide. Teacher education and lifelong learning should therefore not limit digital learning to a means, but also change curricular content and make it into a new way of learning. That should be done both in the case of on-site courses and distant, digital learning models, so that Higher Education and lifelong learning positively change towards facing a new world.

\section{Conclusions}

The present paper analysed digital learning in the context of Higher Education in Brazil. It posited that even though digital learning has the potential to promote both interiorization and internationalization of Higher Education in big and multicultural countries as Brazil, it should be viewed in an inclusionary scenario in order for both provide equality of access and to new curricular and pedagogical ways of learning, using digital means.

The paper argued that multicultural perspectives in Higher Education may help achieving that aim, because they tend to focus on how to answer to cultural diversity in inclusionary, social justice and equity-oriented perspectives. In terms of digital learning, the paper posited a dual perspective: on the one hand, to conceive educational policies focused on expanding access to digital artefacts, so that students of all groups could benefit from them. On the other hand, it claimed there is a need to prepare teachers and Higher Education professors who can adequately articulate digital competence to curriculum and pedagogy, with the view to promote lifelong learners' effective learning, taking into account their cultural worldviews and diversity. 
The paper discussed how setbacks concerning digital learning and lifelong learning have been highlighted with the onset of the pandemics of COVID-19 in Brazil, from March 2020 onwards, with the social distance measures that resulted in the closure of schools and Higher Education institutions, besides commerce and other areas. It discussed the norm that recommended Higher Education institutions to replace on-site classes to on-line, digital learning classes, as well as the challenges and the impacts of such measures in Higher Education.

Lastly, the onset of the pandemic showed we have got to beware of dichotomic thinking that polarises views concerning on-site learning against digital learning. On the contrary, we should perhaps embrace a view that can make both traditional and digital learning as multiculturally oriented, culturally committed and pedagogically challenging. Fighting for equal access of all groups of lifelong learners to technology should be the first step. However, preparing for new ways of learning in multicultural perspectives could be a further step towards promoting transformative curriculum experiences articulated to digital technologies both in present and in on-line courses. Maybe those could be ways ahead for teacher Education and lifelong learning, so that a bright side could emerge after the pandemics, after so much sorrow and loss. 


\section{Educação Permanente Digital e Instituições de Ensino Superior: potenciais e desafios multiculturais em período de pandemia}

\section{Resumo}

$O$ artigo objetiva discutir a aprendizagem digital para a Educação ao longo da vida em nível universitário no Brasil, tomado como estudo de caso. Apresenta conceitos de aprendizagem digital em abordagens multiculturais dentro de paradigmas ao longo da vida. Em seguida, contextualiza políticas educacionais na área, focalizando, particularmente, o papel da Universidade Aberta no Brasil. Por fim, discute a aprendizagem digital no contexto do início da pandemia da COVID-19 no Brasil. Analisa desafios que podem comprometer um potencial multicultural nas politicas educacionais, principalmente, com foco nas diretrizes políticas do governo, discutindo respostas de associações universitárias e de uma universidade pública. Conclui, apresentando possíveis caminhos para reflexões e contribuições futuras na área.

Palavras-chave: Aprendizagem Digital. Aprendizagem ao Longo da Vida. Ensino Superior. COVID-19. Perspectivas Multiculturais. Políticas Educacionais. Brasil.

\section{Educación permanente digital e instituciones de Educación Superior: potenciales y desafíos multiculturales en un período pandémico}

\section{Resumen}

El articulo tiene como objetivo discutir el aprendizaje digital para el aprendizaje permanente a nivel universitario en Brasil, tomado como un estudio de caso. Presenta conceptos de aprendizaje digital en enfoques multiculturales dentro de paradigmas de Educación permanente. Luego realiza una mirada en las políticas educativas brasileñas en esa área, centrándose particularmente sobre el papel de la Universidade Aberta (Universidad Abierta) en Brasil. Por último, analiza el aprendizaje digital en el contexto del inicio de la pandemia de COVID-19 en Brasil en 2020. Trata de medir los impedimentos y los desafios que pueden poner en peligro un potencial multicultural en las políticas educativas, en particular centrándose en las directivas políticas del gobierno, así como en respuestas de asociaciones universitarias y de una universidad pública. Concluye, presentando posibles caminos para reflexiones y contribuciones en el área.

Palabras clave: Aprendizaje Digital. Aprendizaje Permanente. Educación Superior. COVID-19. Perspectivas Multiculturales. Politicas Educativas. Brasil. 


\section{References}

ALA-MUTKA, K., PUNIE, Y.; REDECK, C. Digital competence for lifelong learning: policy brief. Seville: European Commission Joint Research Centre Institute for Prospective Technological Studies; 2008. Available from: http://ipts.jrc.ec.europa.eu/Documents/JRC48708.TN.pdf., 2008. Access in: May 2020.

ÁLVAREZ-MENDIOLA, G. Mexico: great expectations, scattered approaches, disjointed results: the rocky road to lifelong learning in Mexican higher education. In: SCHUETZE, H. G.; SLOWEY, M. (eds.) Global perspectives on higher education and lifelong learners. New York: Routledge, 2012. p. 157-172.

ARAUJO, J. B.; OLIVEIRA, M. G.; BARCELLOS, T. A Covid-19 e a volta às aulas: ouvindo as evidências. Ensaio: Avaliação e Políticas Públicas em Educação, Rio de Janeiro, v. 28, n. 108, p. 555-578, jul./set. 2020. https://doi.org/10.1590/s0104-40362020002802885

BRAZIL. Ministério da Educação. Conselho Nacional de Educação. Parecer $C N E / C P N^{o}$ : 5/2020, 2020a. Reorganização do Calendário Escolar e da possibilidade de cômputo de atividades não presenciais para fins de cumprimento da carga horária mínima anual, em razão da Pandemia da COVID-19. Brasília, DF: Ministério da Educação, 2020a. Available from: https://abmes.org.br/arquivos/legislacoes/Parecer-cne-cp-005-2020-04-28.pdf. Access in: May 2020.

BRAZIL. Ministério da Educação. Portaria No 345/2020. Altera a Portaria MEC n ${ }^{\circ} 343$, de 17 de março de 2020. Diário Oficial da União, 19 mar. 2020b. https://www.in.gov.br/en/web/dou/-/portaria-n-345-de-19-demarco-de-2020-248881422?inheritRedirect=true\&redirect $=\% 2 \mathrm{Fweb} \% 2 \mathrm{Fguest}$ $\% 2$ Fsearch $\% 3 \mathrm{FqSearch} \% 3 \mathrm{DP}$ ortaria\%2520345

BRAZIL. Ministério da Educação. Plano Nacional de Educação. Brasília, DF: Ministério da Educação, 2014. Available from:. http://pne.mec.gov. br/18-planos-subnacionais-de-educacao/543-plano-nacional-de-educacaolei-n-13-005-2014. Access in: Sep. 2019.

BRAZIL. Ministério da Educação. Programa "Future-se". Brasília, DF: Ministério da Educação, 2019a. http://portal.mec.gov.br/busca-geral/12-noticias/ acoesprogramas-e-projetos-637152388/78351-perguntas-e-respostas-do-futureseprograma-de-autonomia-financeira-do-ensino-superior Access in:Dec 2020 
BRAZIL. Ministério da Educação. Portaria No 2.117, 2019b, de 6 de dezembro de 2019. Dispõe sobre a oferta de carga horária na modalidade de Ensino a Distância - EaD em cursos de graduação presenciais ofertados por Instituições de Educação Superior - IES pertencentes ao Sistema Federal de Ensino. Diário Oficial da União, 11 dez. 2019.

BRAZIL. Decreto n ${ }^{0} 5.800$, de 8 de junho de 2006. Dispõe sobre o Sistema Universidade Aberta do Brasil - UAB. Diário Oficial da União, Brasília, DF, 2006 June 9.

CANDAU, V. M. F.; MOREIRA, A. F. B. (eds.). Multiculturalismo: diferenças culturais e práticas pedagógicas. Petrópolis: Vozes, 2008.

DIAS, E. S. A. C.; PINTO, F. C. F. A Educação e a COVID-19. Ensaio: Avaliação e Políticas Públicas em Educação, Rio de Janeiro, v. 28, n. 108, p. 545-554, jul./set. 2020. https://doi.org/10.1590/s0104-40362019002801080001

INSTITUTO NACIONAL DE ESTUDOS E PESQUISAS EDUCACIONAIS ANÍSIO TEIXEIRA - INEP. Censo de Educação Superior 2017: divulgação dos principais resultados. Brasília, DF, 2018. Available from: http://portal.mec.gov.br /censo superior/2017. Access in: Oct. 2020.

IVENICKI, A. Education reform in Brazil: multicultural reflections. In: ORNELAS, C. (ed.). Politics of education in Latin America: reforms, resistance and persistence. Leiden: Koninklijke, 2019. p. 101-115.

IVENICKI, A. Multiculturalismo e formação de professores: dimensões, possibilidades e desafios na contemporaneidade. Ensaio: Avaliação e Políticas Públicas em Educação, Rio de Janeiro, v. 26, n. 100, p. 1151-1167, jul./set. 2018.

KUBOW, P. K.; BLOSSER, A. H., Multicultural education is not enough: the case for comparative education in preservice teacher education. In: KUBOW. P. K.; BLOSSER, A. H. (eds.). Teaching comparative education: trends and issues informing practice. Oxford: Symposium Books, 2016. p. 75- 90.

LOPES, A. C.; OLIVEIRA, A. L. A. R. M.; OLIVEIRA, G. G. S. Apresentação: gênero e sexualidade na educação brasileira- tensões, deslocamentos e horizontes. In: LOPES, A. C.; OLIVEIRA, A. L. A. R. M.; OLIVEIRA, G. G. S. Os gêneros da escola e o (im)possível silenciamento da diferença no currículo. Recife: Ed. UFPe, 2018. p. 7-20. 
MACEDO, E. Currículo como espaço-tempo de fronteira curricular. Revista Brasileira de Educação, Rio de Janeiro, v. 11, n. 32, p.285-296, maio/ago. 2006. https://doi.org/10.1590/S1413-24782006000200007

MILANA, M. Introduction: a global outlook on adult education and learning policies. In: MILANA, M.; NESBIT, T. (eds.). Global perspectives on adult education and learning policies. Hampshire: Palgrave Macmillan, 2015. p. 1-14.

MOREIRA, J. A. et al. Digital learning in higher education: a training course for teaching online. Open Praxis, Oslo, v. 9, n. 2, p. 253-263, Apr.-June 2017. https://doi.org/10.5944/openpraxis.9.2.539

NESBIT, T. Conclusion: global developments in adult education policy. In: MILANA, M.; NESBIT, T. (eds.). Global perspectives on adult education and learning policies. Hampshire: Palgrave Macmillan, 2015. p. 237-251.

NITAHARA, A. Acesso ao ensino superior no Brasil é abaixo dos padrões internacionais. Agência Brasil, Brasília, DF, nov. 2019. Available from: https://agenciabrasil.ebc.com.br/economia/noticia/2019-11/, 2019. Acess in: 2020 May 19.

SLOWEY, M.; SCHUETZE, H. G. All change - no change? Lifelong learners and higher education revisited. In: SCHUETZE, H. G.; SLOWEY, M. (eds.) Global perspectives on higher education and lifelong learners. New York: Routledge, 2012. p. 1-22.

\section{Information about the author}

Ana Ivenicki: $\mathrm{PhD}$ in Education from the University of Glasgow, Scotland. Profesor Emeritus at the Universidade Federal do Rio de Janeiro, Programa de Pós-Graduação em Educação. She is the chair of the Multicultural Studies Group (Grupo de Estudos Multiculturais - GEM), and a Researcher (Pesquisadora 1A) of the Brazilian National Research Council (CNPq). Contato: aivenicki@gmail.com

(iD) https://orcid.org/0000-0002-7315-5500 